\title{
Antioxidant, Antimicrobial, Cytotoxic, Larvicidal and Anthelmintic Activities and Phenolic Contents of Cyclamen alpinum
}

\author{
Murat Turan*, Ramazan Mammadov \\ Department of Biology, Faculty of Art \& Science, Pamukkale University, Denizli, Turkey \\ Email: *rmammad@yahoo.com
}

How to cite this paper: Turan, M. and Mammadov, R. (2018) Antioxidant, Antimicrobial, Cytotoxic, Larvicidal and Anthelmintic Activities and Phenolic Contents of Cyclamen alpinum. Pharmacology \& Pharmacy, 9, 100-116.

https://doi.org/10.4236/pp.2018.94008

Received: September 10, 2017

Accepted: April 27, 2018

Published: April 30, 2018

Copyright (c) 2018 by authors and Scientific Research Publishing Inc. This work is licensed under the Creative Commons Attribution International License (CC BY 4.0).

http://creativecommons.org/licenses/by/4.0/

\begin{abstract}
In this study, antioxidant, cytotoxic, larvicidal, antimicrobial and anthelmintic effects and phenolic contents of ethanol, methanol and acetone extracts of leaf and tuber parts of Cyclamen alpinum were investigated. DPPH, ABTS, $\beta$-carotene assays were carried out in antioxidant activity and total phenolic and flavonoid contents were tested in determination assay. 9 phenolic contents were determined by HPLC. Artemia salina was used in the cytotoxic effect. Larvicidal effect was investigated against Culex pipiens. Disc diffusion method was used in antimicrobial effect. The tuber part was found to be more toxic than the leaf part in the anthelmintic activity assay. The highest value obtained from the antioxidant activity experiment was observed with value of $86.73 \pm 0.16(\%)$ in $\mathrm{DPPH}$ assay. The lowest $\mathrm{LC}_{50}$ value in larvicidal effect was determined $0.151 \mathrm{mg} / \mathrm{mL}$ after 72 hours. Consequently, there is need for further studies on the Cyclamen alpinum, which has the ability to fight against diseases such as cancer, cardiovascular diseases, etc.
\end{abstract}

\section{Keywords}

Antioxidant Activity, Antimicrobial Activity, Cytotoxic Activity, Larvicidal Activity, Cyclamen alpinum

\section{Introduction}

Free radicals are substances in which atoms in normal or pathological cells contain one or more unpaired electrons and they are very unstable [1] [2] [3] and they can react very easily with organic molecules such as lipids, proteins, carbohydrates and DNA. Also, they are thought to be responsible for many diseases such as aging, cancer, diabetes, liver diseases, Parkinson's disease and Alzheimer's disease [4] [5] [6] [7]. Therefore, defense against free radicals is crucial in 
reducing the risk of developing these diseases [8].

Antioxidants are compounds that protect molecules by inhibiting the initiation or propagation of oxidant chain reactions caused by free radicals. Antioxidants are divided into natural and synthetic [9]. It is more likely that synthetic antioxidants used in the industry due to their strong biological activity have side effects and are carcinogenic accelerators [6]. Because of this reason, the need for natural antioxidants has begun to become more important, and the search for natural antioxidant-containing plants has gained importance in recent years [10]. Plants and plant products are rich antioxidant sources and epidemiological studies have revealed the relationship between plant antioxidants, chronic and oxidative diseases [8] [11].

The genus Cyclamen, which possesses geofit plant species, belongs to the family of Primulaceae [12]. Cyclamen plants are used as medicinal plants and also used as ornamental plants [13]. Cyclamen alpinum Dammann ex. Sprenger was identified by Schwarz as endemic under the name Cyclamen trochopteranthum O. Schwarz in 1975 but nowadays although it is again called Cyclamen alpinum, its endemism is controversial [14]. Some species of this genus are used in folk medicine. In a few studies, some species of this genus have been reported to have antifungal, antiinflammatory and antinociceptive activities [15] [16].

Although this study is not the first study of $C$. alpinum species, it has been carried out to fill the gaps in the literature and to expand the studies on this species. In a study by Arslan et al. [17], C. trochopteranthum (C. alpinum) tuber extract might have a potential not only to inhibit and/or induce the metabolism of certain co-administered drugs but also to influence the development of toxicity and carcinogenesis owing to the induction of the cytochrome P450-dependent drug-metabolizing enzymes. $\mathrm{Oz}$ et al. [15] investigated the larvicidal activity against Culex pipiens L. (Diptera: Culicidae) of the ethanolic extracts of the tuber parts of $C$. alpinum and Cyclamen mirabile Hildebr. species. They showed that $C$. mirabile (86.2 ppm) was more active than C. alpinum (161.3 ppm) according to LC $_{50}$ values. In Gündoğan's [18] study, the antimicrobial activity of the C. mirabile and C. alpinum species (bacteria: Bacillus subtilis and Escherichia coli, fungi: Candida albicans), was not found antimicrobial activity against bactericides, but $12 \mathrm{~mm}$ inhibition zone of antifungal activity. In the same study, C. mirabile and $C$. alpinum species were found to be more effective in acetone extracts $\left(\mathrm{IC}_{50}: 48.33 \mathrm{ppm}\right)$ in the $\mathrm{DPPH}$ assay with petroleum ether and acetone extracts [18].

The aim of this study was to investigate the phenolic compounds, antioxidant, cytotoxic, larvicidal, antimicrobial and anthelmintic activity of various solvent extracts of $C$. alpinum tubers and leaves. The findings obtained from this study can increase the overall value of the medical potential of the plant.

\section{Materials and Methods}

\subsection{Materials}

Leaves and tubers of $C$. alpinum were collected from their habitats in Denizli, 
Turkey, in March-April 2015, identified from the book of Flora of Turkey [12]. Each parts (tubers and leaves) were dried at the shadow, room temperature and low humidity.

\subsection{Extraction}

Dried samples were pulverized with blender then $10 \mathrm{~g}$ samples were transferred to each $250 \mathrm{~mL}$ 's erlenmeyers and ethanol, methanol or acetone were poured 100 $\mathrm{mL}$ into erlenmeyers. Erlenmeyers were put in a shaker water bath (Memmert WNB 22) at $49^{\circ} \mathrm{C}$ for $6 \mathrm{~h}$. Then the mixture of extraction was filtered with Whatmann No: 1 filter paper. This process was repeated twice time. The solvents were separated by rotary evaporator (Ika RV 10) at $48^{\circ} \mathrm{C}-49^{\circ} \mathrm{C}$. The water inside extracts were frozen at $-80^{\circ} \mathrm{C}$ and drawn out with freze-dryer (Labconco Freezone 6) at $-54^{\circ} \mathrm{C}$. Extracts were stored in $-20^{\circ} \mathrm{C}$ [19].

\subsection{Assay of DPPH Free Radical Scavenging Activity}

2.2-diphenyl-1-picrylhydrazyl (DPPH) free radical was used for determined the scavenging activity according to method of $\mathrm{Wu}$ et al. [20]. Five concentrations of extracts $(0.2 \mathrm{~mL}, 0.4 \mathrm{~mL}, 0.6 \mathrm{~mL}, 0.8 \mathrm{~mL}$ and $1.0 \mathrm{~mL})$ and Butylated Hydroxyanisole (BHA) (for positive control) with solvents (ethanol, methanol or acetone) were mixed with $4 \mathrm{~mL}$ of $0.004 \%$ methanol solution of DPPH. The mixtures were incubated $30 \mathrm{~min}$ at room temperature in dark and were measured at 517 $\mathrm{nm}$ in spectrophotometer. Three replicates of each concentration were run at a time. The scavenging activity $(S A)(1)$ was calculated with formula of

$$
S A \%=\left[\frac{A_{b}-A_{s}}{A_{b}}\right] * 100
$$

where $A_{b}$ is the absorbance value of the control (methanol) and $A_{s}$ is the absorbance value of sample involving extract.

\subsection{Assay of $\beta$-Carotene-Linoleic Acid}

The antioxidant activity of extracts was measured with $\beta$-carotene-linoleic acid model system according to method of Amin et al. [21]. $2 \mathrm{mg} \beta$-carotene and 10 $\mathrm{mL}$ chloroform were mixed to prepare $\beta$-carotene stock solution and $1 \mathrm{~mL}$ from stock solution transferred to a beaker. $40 \mathrm{mg}$ linoleic acid and $400 \mathrm{mg}$ Tween 20 were added to beaker. Chloroform was seperated in the rotary evaporator and was added $100 \mathrm{~mL}$ distille water. $4.8 \mathrm{~mL}$ of the emulsion was added into test tubes which had $0.2 \mathrm{mg}$ of the sample and $0.2 \mathrm{~mL}$ of the extract in them, then initial absorbances were measured at $470 \mathrm{~nm}$ in spectrophotometer. BHA was used for positive control. The test tubes were measured every $30 \mathrm{~min}$ until $2 \mathrm{~h}$ while they were incubated at $50^{\circ} \mathrm{C}$. The antioxidant activity $(A A)(2)$ of $\beta$-carotene-linoleic acid model system was calculated with formula of

$$
A A \%=\left[1-\left(\frac{A_{0 s}-A_{0 c}}{A_{2 s}-A_{2 c}}\right)\right] * 100
$$


where $A_{0 s}$ is the initial absorbance value of sample, $A_{0 c}$ is the initial value of control, $A_{2 s}$ is the absorbance value of sample at $2 \mathrm{~h}$ and $A_{2 c}$ is the absorbance value of control at $2 \mathrm{~h}$.

\subsection{Assay of ABTS Radical Cation Scavenging Activity}

2.2'-azino-bis (3-ethylbenzothiazoline-6-sulphonic acid) (ABTS) radical cation was used for determined the scavenging activity according to method of Re et al. [22]. ABTS radical cation was produced with $7 \mathrm{mM}$ ABTS solution and $2.45 \mathrm{~mm}$ potassium persulfate. The mixture was stood $12 \mathrm{~h}$ in dark at the room temperature. Before using the mixture was diluted with methanol to obtain an absorbance $734 \mathrm{~nm}$ with using the spectrophotometer. $3 \mathrm{~mL}$ sample solution was mixed with $2 \mathrm{~mL}$ ABTS solution. The mixture was incubated $30 \mathrm{~min}$ at room temperature. The absorbance was measured at $734 \mathrm{~nm}$ in spectrophotometer. The scavenging activity $(S A)$ (3) was calculated formula of

$$
S A \%=\left[\frac{A_{b}-A_{s}}{A_{b}}\right] * 100
$$

where $A_{b}$ is the absorbance value of the control (methanol) and $A_{s}$ is the absorbance value of sample involving extract.

\subsection{Determination of Total Phenolic Contents}

Total phenolic contents were determined with Folin-Ciocalteu method according to Slinkard and Singleton [23]. Gallic acid was used for equivalent. $1 \mathrm{mg}$ sample was mixed with $46 \mathrm{~mL}$ distille water and $1 \mathrm{~mL}$ Folin-Ciocalteu reagent (FCR) was added in mixture. After $3 \mathrm{~min}, 3 \mathrm{~mL}, 2 \%$ sodium carbonate $\left(\mathrm{Na}_{2} \mathrm{CO}_{3}\right)$ was added to mixture and shaken intermittently along $2 \mathrm{~h}$. The absorbance was measured at $760 \mathrm{~nm}$ in spectrophotometer. Three replicates of each concentration were run at a time. Total phenolic contents were calculated with standard gallic acid graph and were determined as micrograms of gallic acid equivalent per gram of dry matter.

\subsection{Determination of Total Flavonoid Contents}

Total flavonoid contents were determined used method by Arvouet-Grand et al. [24]. Quercetin was used for equivalent. $1 \mathrm{~mL}$ sample and $1.0 \mathrm{~mL} 2 \%$ aluminium trichloride $\left(\mathrm{AlCl}_{3}\right)$ in methanol were added the test tubes. The mixture was incubated for $10 \mathrm{~min}$. The absorbance was measured at $415 \mathrm{~nm}$ in spectrophotometer. Total flavonoid contents were calculated with standard quercetin graph.

\subsection{Assay of Brine Shrimp (Artemia salina) Cytotoxicity Activity}

The Brine Shrimp cytotoxicity activity with Artemia salina of the extracts was determined according to method of Krishnaraju et al. [25]. A. salina eggs (10 $\mathrm{mg}$ ) were incubated in $500 \mathrm{~mL}$ factitious seawater at $28^{\circ} \mathrm{C}$ for $48 \mathrm{~h}$. After incubation, 10 nauplii were added to each vial containing $4.5 \mathrm{~mL}$ of brine solution. 0.5 $\mathrm{mL}$ of four concentration $(0.1 \mathrm{mg} / \mathrm{mL}, 0.25 \mathrm{mg} / \mathrm{mL}, 0.5 \mathrm{mg} / \mathrm{mL}, 1 \mathrm{mg} / \mathrm{mL})$ of 
extracts were added to brine solution, respectively. The mixtures were incubated $24 \mathrm{~h}$ at $28^{\circ} \mathrm{C}$. Then dead nauplii were recorded under the light. $\mathrm{LC}_{50(\mathrm{~min})}, \mathrm{LC}_{50}$ $(\max ), \mathrm{LC}_{50}, \mathrm{LC}_{90}$, chi-square $\left(x^{2}\right)$ were calculated with Probit analysis in STATPLUS Pro 5.9.8.

\subsection{Analysis of Phenolic Compounds in HPLC}

Analysis of phenolic compounds in High Performance Liquid Chromatography (HPLC) with standards was performed with modified according to method of Caponio et al. [26] with Photodiode Array Detector (SPD-M20A) and LC20 AT pump. The analysis was carried out C-18 column $(250 \mathrm{~mm} \times 4.6 \mathrm{~mm}, 2.5 \mu \mathrm{m})$ with CTO-10ASVp column oven. The mobile phases were solvent A: $3.0 \%$ formic acid in distilled water and solvent B: methanol. $0.2 \mathrm{~g}$ sample was dissolved in mobile phase. Then sample was filtrated in $0.45 \mu \mathrm{m}$ and was injected to the HPLC. The elution gradient applied at a flow rate of $0.8 \mathrm{~mL} \cdot \mathrm{min}^{-1}$ with $95 \% \mathrm{~A}$ for $3 \mathrm{~min}, 70 \% \mathrm{~A}$ in $47 \mathrm{~min}, 30 \% \mathrm{~A}$ in $23 \mathrm{~min}, 100 \% \mathrm{~A}$ in $7 \mathrm{~min}$. Gallic acid, 3.4-hydroxybenzoic acid, 4-hydroxybenzoic acid, chlorogenic acid, vanillic acid, caffeic acid, p-coumaric acid, ferulic acid, cinnamic acid were used as standards.

\subsection{Assay of Larvicidal Activity to Mosquito (Culex pipiens) Larvae}

Larvicidal activity to mosquito ( $C x$. pipiens) larvae of the extracts was investigated according to method of Çetin et al. [27]. Four concentrations $(0.1 \mathrm{mg} / \mathrm{mL}$, $0.25 \mathrm{mg} / \mathrm{mL}, 0.5 \mathrm{mg} / \mathrm{mL}, 1 \mathrm{mg} / \mathrm{mL}$ ) of extracts were dissolved in $100 \mathrm{~mL}$ distilled water in beakers. 10 larvae were transferred to beakers and fish food was given to the larvae. The experiment was carried out $12: 12$ (L: D) photoperiod, $26^{\circ} \mathrm{C}$ and $60 \%$ humidity. Died larvae were recorded 24-, 48-, 72-h of exposure. LC $_{50(\min )}$, $\mathrm{LC}_{50(\max )}, \mathrm{LC}_{50}, \mathrm{LC}_{90}$, chi-square $\left(x^{2}\right)$ were calculated with probit analysis in STATPLUS Pro 5.9.8.

\subsection{Assay of Antimicrobial Activity}

The antimicrobial activity of the extracts with disc diffusion method was determined according to method of Collins et al. [28]. Escherichia coli ATCC 35218, Staphylococcus aureus ATCC 25923, Staphylococcus aureus ATCC 12598, Pseudomonas aeruginosa NRLL B-23, Bacillus subtilis ATCC 6633, Bacillus cereus RSKK 863 for bacterial assay and Candida albicans ATCC 10239 for fungal assay were used in this experiment. The fungi was cultivated in Sabouraud Dextrose Broth at $28^{\circ} \mathrm{C}$ for $48 \mathrm{~h}$ and bacteria were cultivated in Nutrient Broth at $37^{\circ} \mathrm{C}$ for $24 \mathrm{~h} .1 \mathrm{mg} / \mathrm{mL}$ concentration of extracts were saturated into paper disc $6 \mathrm{~mm}$ in diameter. Only solvent was used for control. Ampicilin (10 $\mu \mathrm{g})$ and Penicilin (10 U) were used for positive control. Discs that should have bacteria and fungi on the agar plate were placed. The petri dishes were incubated at $37^{\circ} \mathrm{C}$ for $24 \mathrm{~h}$ for bacteria and at $28^{\circ} \mathrm{C}$ for $48 \mathrm{~h}$ for the fungi. The diameter of inhibition in petri dishes was calculated with ruler as $\mathrm{mm}$. 


\subsection{Assay of Anthelmintic Activity}

The anthelmintic activity of theextracts were determined with modifications according to method of Ajaiyeoba et al. [29]. The Tubifex tubifex of nearly 2 - 3 $\mathrm{cm}$ size, ten in each group was taken for the experiment. Six concentrations of extracts with ethanol solvent $(1 \mathrm{mg} / \mathrm{mL}, 2.5 \mathrm{mg} / \mathrm{mL}, 5 \mathrm{mg} / \mathrm{mL}, 10 \mathrm{mg} / \mathrm{mL}, 20$

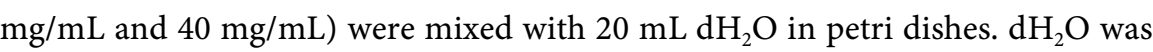
used for negative control. Each petri dish were put 10 helminths and died helminths were recorded at 2-, 4-, 6-min of exposure in room temperature. $\mathrm{LC}_{50}$ (min) $, \mathrm{LC}_{50(\max )}, \mathrm{LC}_{50}, \mathrm{LC}_{90}$, chi-square $\left(x^{2}\right)$ were calculated with probit analysis in STATPLUS Pro 5.9.8.

\subsection{Statistical Analysis}

In all experiments, three replicates of each concentration were run at the same time. The standart errors of mean of experiments were analyzed and all experiments except the anthelmintic activity test were compared with the ANOVA-Duncan test by using SPSS Version 23.0 [30].

\section{Results and Discussion}

\subsection{Antioxidant Activity and Determination Assays}

Free radicals can result in various diseases such as cancer, cataract, aging, etc. Therefore, antioxidants that can quench free radicals may be implicated in the prevention of these diseases [20]. Assessment of the antioxidant activity of plants, cannot be performed any single method because no single assay could accurately reflect all antioxidants for a mixed or complex system [2] [31]. Therefore, ethanol, methanol and acetone solvent extracts of $C$. alpinum leaf and tuber parts were examined by DPPH and ABTS assays for scavenging effect, FRAP and beta-carotene assays for antioxidant activities, determination assays for total phenolic contents and total flavonoid contents.

DPPH radical scavenging activity test is widely used to test for compounds acting as hydrogen donor for the free radical scavenging [32]. In assay of DPPH, the highest free radical scavenging activity $(86.73 \% \pm 0.16 \%)$ was recorded on acetone extract of tuber part with $1 \mathrm{mg} / \mathrm{mL}$ concentration. Also free radical scavenging activity $(97.50 \% \pm 0.50 \%)$ was recorded on methanol extract of BHA with $1 \mathrm{mg} / \mathrm{mL}$ concentration for comparison.

In leaf part, there is statistical difference between all concentrations at ethanol and methanol solvents $(p<0.005)$, no statistical difference between $0.8 \mathrm{mg} / \mathrm{mL}$ and $1.0 \mathrm{mg} / \mathrm{mL}$ at acetone solvent in terms of concentration $(p>0.005)$. There is no statistical difference between ethanol and methanol at concentration of 0.4 $\mathrm{mg} / \mathrm{mL}$ in terms of solvent $(p>0.005)$. In tuber part, there is statistical difference between all concentrations of whole solvents in terms of concentration $(p<$ 0.005). There is statistical difference between overall concentrations of all solvents in terms of concentration $(p<0.005)$. In standard of BHA, there is statistical difference between all concentrations of all solvents in terms of concentra- 
tion $(p<0.005)$. There is no statistical difference between ethanol and acetone at concentration of $0.4 \mathrm{mg} / \mathrm{mL}$ and statistical difference between all solvents of 0.6 $\mathrm{mg} / \mathrm{mL}, 0.8 \mathrm{mg} / \mathrm{mL} 1.0 \mathrm{mg} / \mathrm{mL}$ in terms of solvent $(p>0.005)$, no statistical difference between whole solvents at concentration of $0.2 \mathrm{mg} / \mathrm{mL}(p>0.005)$ (Table 1). Gündoğan [18] has found that $C$. mirabile and $C$. alpinum plants acetone extract is more effective than petroleum ether extract.

As the plant concentrations used in the study increased, the amount of DPPH free radicals increased. It was observed that the tuber part was more active than the leaf part and showed that it could act as a free radical scavenger when 1.0 $\mathrm{mg} / \mathrm{mL}$ was taken into consideration. The reason showing different antioxidant activity of the same plants extracts can be polarities of the solvents [19].

The ABTS radical cation scavenging activity is generally one of the methods used to measure the hydrogen donating and chain breaking capacity of plant extracts [2]. In assay of ABTS, the highest free radical scavenging activity $(76.21 \%$ $\pm 0.32 \%$ ) was recorded on leaf part with acetone extract with $40 \mathrm{mg} / \mathrm{mL}$ concentration. Also, free radical scavenging activity $(97.10 \% \pm 0.33 \%)$ was recorded on ethanol extract of BHA for comparison (Table 2). In leaf part, there is statistical difference between all concentrations with whole solvents in terms of concentration

Table 1. Free-radical scavenging activity (\%) of C. alpinum extracts with DPPH assay (Mean \pm S.E.).

\begin{tabular}{|c|c|c|c|c|c|c|c|c|c|}
\hline \multirow[b]{2}{*}{ Concentrations } & \multicolumn{3}{|c|}{ Leaf Part } & \multicolumn{3}{|c|}{ Tuber Part } & \multicolumn{3}{|c|}{ BHA } \\
\hline & Ethanol & Methanol & Acetone & Ethanol & Methanol & Acetone & Ethanol & Methanol & Acetone \\
\hline \multirow{2}{*}{$0.2 \mathrm{mg} / \mathrm{mL}$} & $22.07 \pm 0.30$ & $26.19 \pm 0.14$ & $33.01 \pm 0.33$ & $13.11 \pm 0.32$ & $23.43 \pm 0.40$ & $20.98 \pm 0.27$ & $50.20 \pm 0.66$ & $58.46 \pm 0.44$ & $55.70 \pm 0.66$ \\
\hline & $\mathrm{a}^{x}, \mathrm{~A}^{y}$ & $\mathrm{~b}, \mathrm{~A}$ & $\mathrm{c}, \mathrm{A}$ & $\mathrm{a}^{x}, \mathrm{~A}^{y}$ & b, A & c, $A$ & $\mathrm{a}^{x}, \mathrm{~A}^{y}$ & $\mathrm{~b}, \mathrm{~A}$ & c, $\mathrm{A}$ \\
\hline \multirow{2}{*}{$0.4 \mathrm{mg} / \mathrm{mL}$} & $37.41 \pm 0.32$ & $28.33 \pm 0.16$ & $61.66 \pm 0.34$ & $24.37 \pm 0.24$ & $27.07 \pm 0.25$ & $48.40 \pm 0.16$ & $68.47 \pm 0.86$ & $69.47 \pm 0.50$ & $66.47 \pm 0.55$ \\
\hline & a, B & $\mathrm{a}, \mathrm{B}$ & $\mathrm{b}, \mathrm{B}$ & $\mathrm{a}, \mathrm{B}$ & $\mathrm{b}, \mathrm{B}$ & $c, B$ & $a b, B$ & $\mathrm{~b}, \mathrm{~B}$ & $\mathrm{a}, \mathrm{B}$ \\
\hline \multirow{2}{*}{$0.6 \mathrm{mg} / \mathrm{mL}$} & $48.17 \pm 0.53$ & $31.90 \pm 0.30$ & $82.97 \pm 0.18$ & $31.10 \pm 0.34$ & $31.07 \pm 0.14$ & $73.43 \pm 0.71$ & $76.22 \pm 0.63$ & $79.23 \pm 0.87$ & $78.23 \pm 0.43$ \\
\hline & a, C & $\mathrm{b}, \mathrm{C}$ & c, C & a, C & $\mathrm{b}, \mathrm{C}$ & c, C & $\mathrm{a}, \mathrm{C}$ & $\mathrm{b}, \mathrm{C}$ & $a b, C$ \\
\hline \multirow{2}{*}{$0.8 \mathrm{mg} / \mathrm{mL}$} & $58.76 \pm 0.67$ & $33.81 \pm 0.33$ & $84.85 \pm 0.62$ & $35.23 \pm 0.37$ & $34.57 \pm 0.29$ & $83.79 \pm 0.21$ & $88.74 \pm 0.75$ & $90.74 \pm 0.38$ & $89.99 \pm 0.63$ \\
\hline & a, D & $\mathrm{b}, \mathrm{D}$ & $\mathrm{c}, \mathrm{D}$ & a, D & $\mathrm{b}, \mathrm{D}$ & $c, D$ & a, D & a, D & a, D \\
\hline \multirow{2}{*}{$1.0 \mathrm{mg} / \mathrm{mL}$} & $68.84 \pm 0.43$ & $37.93 \pm 0.08$ & $85.82 \pm 0.40$ & $37.68 \pm 0.40$ & $37.19 \pm 0.79$ & $86.73 \pm 0.16$ & $96.50 \pm 0.50$ & $97.50 \pm 0.50$ & $96.75 \pm 0.50$ \\
\hline & a, E & $\mathrm{b}, \mathrm{E}$ & $c, D$ & a, E & $\mathrm{b}, \mathrm{E}$ & $c, E$ & a, E & a, E & $\mathrm{a}, \mathrm{E}$ \\
\hline
\end{tabular}

$x$. If lower cases are same in a line, there is no statistical difference in Duncan's multiple range test $(p \leq 0.05) . y$. If lower cases are same in a column, there is no statistical difference in Duncan's multiple range test $(p \leq 0.05)$.

Table 2. ABTS radical cation scavenging activity (\%) of $C$. alpinum extracts with ABTS assay (Mean \pm S.E.).

\begin{tabular}{ccccccccccc}
\hline & \multicolumn{3}{c}{ Leaf Part } & \multicolumn{3}{c}{ Tuber Part } & & BHA \\
\hline Concentrations & Ethanol & Methanol & Acetone & Ethanol & Methanol & Acetone & Ethanol & Methanol & Acetone \\
\hline \multirow{2}{*}{$10 \mathrm{mg} / \mathrm{mL}$} & $35.90 \pm 0.29$ & $39.56 \pm 0.24$ & $38.59 \pm 0.55$ & $30.55 \pm 0.36$ & $35.54 \pm 0.32$ & $32.16 \pm 0.20$ & $62.40 \pm 0.22$ & $69.20 \pm 0.39$ & $68.17 \pm 0.22$ \\
& $\mathrm{a}^{x}, \mathrm{~A}^{y}$ & b, A & b, A & $\mathrm{a}^{x}, \mathrm{~A}^{y}$ & b, A & c, A & $\mathrm{a}^{x}, \mathrm{~A}^{y}$ & b, A & c, A \\
$20 \mathrm{mg} / \mathrm{mL}$ & $55.84 \pm 0.15$ & $68.20 \pm 0.40$ & $65.21 \pm 0.21$ & $52.57 \pm 0.38$ & $58.50 \pm 0.33$ & $55.84 \pm 0.15$ & $85.10 \pm 0.33$ & $90.00 \pm 0.29$ & $88.40 \pm 0.38$ \\
& a, B & b, B & c, B & a, B & b, B & c, B & a, B & b, B & c, B \\
$40 \mathrm{mg} / \mathrm{mL}$ & $63.11 \pm 0.20$ & $72.86 \pm 0.22$ & $76.21 \pm 0.32$ & $61.86 \pm 0.81$ & $65.52 \pm 0.37$ & $63.11 \pm 0.20$ & $97.10 \pm 0.33$ & $95.85 \pm 0.23$ & $96.50 \pm 0.32$ \\
& a, C & b, C & c, C & a, C & b, C & c, C & a, C & b, C & b, C \\
\hline
\end{tabular}

$x$. If lower cases are same in a line, there is no statistical difference in Duncan's multiple range test $(p \leq 0.05)$. $y$. If lower cases are same in a column, there is no statistical difference in Duncan's multiple range test $(p \leq 0.05)$. 
$(p<0.005)$. There is no statistical difference between methanol and acetone at concentration of $10 \mathrm{mg} / \mathrm{mL}(p>0.005)$ and but there is statistical difference between ethanol and methanol, ethanol and acetone at concentration of $10 \mathrm{mg} / \mathrm{mL}$ in terms of solvent $(p<0.005)$. Additionally, there is statistical difference between all solvents at the other concentrations $(20 \mathrm{mg} / \mathrm{mL}, 40 \mathrm{mg} / \mathrm{mL})$ in terms of solvent $(p<0.005)$. In tuber part, there is statistical difference between all concentrations with overall solvents in terms of concentration $(p<0.005)$. There is statistical difference between all solvents at whole concentrations in terms of solvent $(p<0.005)$. In standard of BHA, there is statistical difference between in all concentrations of all solvents in terms of concentration $(p<0.005)$.

The result of DPPH scavenging activity was found to be higher than that of ABTS cation scavenging activity. Wang et al. [33] reported a correlation between DPPH and ABTS assays but Wang et al. [34] found that some active compounds in ABTS scavenging activity which not effective at DPPH scavenging activity, according to this work, the highest scavenging activity between ABTS and DPPH results weren't been in the same part and nearly ratio.

In the $\beta$-carotene assay, the speed of $\beta$-carotene color change in the presence of antioxidants in the linoleic acid medium decreases and the characteristic yellow color is preserved. In this assay, antioxidant activity can be mentioned when the color is preserved [35] [36]. The results were depicted in Table 3. In tuber part of all extracts was exhibited higher antioxidant activity than in leaf part of all extracts. The highest antioxidant activity $(83.35 \pm 0.29)$ was recorded on acetone extract of leaf part and acetone extract of BHA $(94.70 \pm 0.18)$ was recorded for comparison. There is no statistical difference between in all solvents $(p>$ $0.005)$.

Antioxidant activity occurs due to the natural polyphenolic compounds present in plant extracts [1] [37]. The power of eliminating the free radicals of the hydroxyl groups in these compounds is very important [5]. For this reason, the amount of polyphenolic compounds in plant content is important, since plants containing high polyphenolic compounds will be important antioxidant sources [32]. In determination of total phenolic contents, the highest value (8.95 $\pm 0.17 \mathrm{mg} \mathrm{GAE} / \mathrm{g}$ ) was recorded on acetone extract of leaf part but there is no statistical difference between the all values $(p>0.005)$. In determination of total flavonoid contents, the highest value was $92.63 \pm 0.45 \mathrm{mg} Q \mathrm{QE} / \mathrm{g}$ on acetone extract of leaf part (Table 4). In leaf part, there is statistical difference between

Table 3. Antioxidant activity (\%) of $C$. alpinum extracts with $\beta$-carotene-linoleic acid assay (Mean \pm S.E.).

\begin{tabular}{ccccccccc}
\hline & Leaf Part & \multicolumn{3}{c}{ Tuber Part } & \multicolumn{3}{c}{ BHA } \\
\hline Ethanol & Methanol & Acetone & Ethanol & Methanol & Acetone & Ethanol & Methanol & Acetone \\
\hline $62.40 \pm$ & $72.27 \pm$ & $83.35 \pm$ & $63.44 \pm$ & $66.08 \pm$ & $69.74 \pm$ & $92.50 \pm$ & $94.05 \pm$ & \\
0.28 & 0.37 & 0.29 & 0.58 & 0.16 & 0.16 & 0.23 & 0.18 & $94.70 \pm 0.18$ \\
$\mathrm{a}^{X}$ & $\mathrm{~b}$ & $\mathrm{c}$ & $\mathrm{a}^{\mathrm{x}}$ & $\mathrm{b}$ & $\mathrm{c}$ & $\mathrm{a}^{\mathrm{x}}$ & $\mathrm{b}$ & $\mathrm{c}$ \\
\hline
\end{tabular}

$x$. If upper cases are same in a line, there is no statistical difference in Duncan's multiple range test $(p \leq$ $0.05)$. 
Table 4. Determination of $C$. alpinum extracts with Total Phenolic Contents and Total Flavonoid Contents assays (Mean \pm S.E.). (a) Total Phenolic Contents (mg GAE/g); (b) Total Flavonoid Contents (mg QE/g).

(a)

\begin{tabular}{cccccc}
\hline \multicolumn{5}{c}{ Total Phenolic Contents (mg GAE/g) } \\
\hline Leaf Part & \multicolumn{3}{c}{ Tuber Part } \\
\hline Ethanol & Methanol & Acetone & Ethanol & Methanol & Acetone \\
$8.45 \pm 0.25$ & $8.60 \pm 0.23$ & $8.95 \pm 0.17$ & $7.42 \pm 0.22$ & $8.05 \pm 0.11$ & $8.10 \pm 0.28$ \\
$\mathrm{a}^{x}$ & $\mathrm{a}$ & $\mathrm{a}$ & $\mathrm{a}^{\mathrm{X}}$ & $\mathrm{a}$ & $\mathrm{a}$ \\
\hline
\end{tabular}

(b)

\begin{tabular}{cccccc}
\hline \multicolumn{5}{c}{ Total Flavonoid Contents $(\mathrm{mg}$ QE/g) } \\
\hline Leaf Part & \multicolumn{3}{c}{ Tuber Part } \\
\hline Ethanol & Methanol & Acetone & Ethanol & Methanol & Acetone \\
$47.25 \pm 0.50$ & $55.33 \pm 0.45$ & $92.63 \pm 0.45$ & $3.85 \pm 0.20$ & $3.98 \pm 0.19$ & $14.32 \pm 0.36$ \\
$\mathrm{a}^{x}$ & $\mathrm{~b}$ & $\mathrm{c}$ & $\mathrm{a}^{x}$ & $\mathrm{a}$ & $\mathrm{b}$ \\
\hline
\end{tabular}

$x$. If upper cases are same in a line, there is no statistical difference in Duncan's multiple range test ( $p \leq$ $0.05)$.

all solvents terms of concentration $(p<0.005)$. Polyphenols play an active role in preventing important diseases like cancer risk and in protecting human health [7]. Therefore, the amount of phenolic compounds and flavonoid of Cyclamen alpinum can be considered to have the potential.

\subsection{Assay of Brine Shrimp (Artemia salina) Cytotoxicity Activity}

The brine shrimp lethality assay is a rapid, inexpensive and simple biological assay of plant extracts, generally showing positive correlation with cytotoxic and antitumor properties [25] [38] [39] [40]. In this work, $A$. salina species and $C$. alpinum ethanol extracts were used. The results of cytotoxic activity of $C$. alpinum extracts are presented in Table 5. The $\mathrm{LC}_{50}$ values of the plant extracts were obtained by a plot of percentage of the shrimp nauplii killed against the concentrations of the extracts. The best-fit line was obtained from the data by means of regression analysis in Figure 1 [25]. The tuber part was showed most prominent lethality activity with $\mathrm{LC}_{50}(0.257 \mathrm{mg} / \mathrm{mL})$. As the $\mathrm{LC}_{50}$ value decreases, the lethality effect increases. In tuber part, there is statistical difference between all concentrations $(p<0.005)$. In leaf part, there is no statistical difference between $0.1 \mathrm{mg} / \mathrm{mL}$ and $0.25 \mathrm{mg} / \mathrm{mL}(p<0.005)$ but statistical difference between the other concentrations $(p>0.005)$. The degree of lethality was found to be directly proportional to the concentration of extract. This deadly effect may be responsible for the saponins, alkaloids and cardiac glycosides which may be more at the tuber part in the plant, and the results show that plant extracts have the pharmacological effect.

\subsection{Assay of Larvicidal Activity to Mosquito (Culex pipiens) Larvae}

The percentage of mortality in which the ethanolic extracts of tuber and leaf 


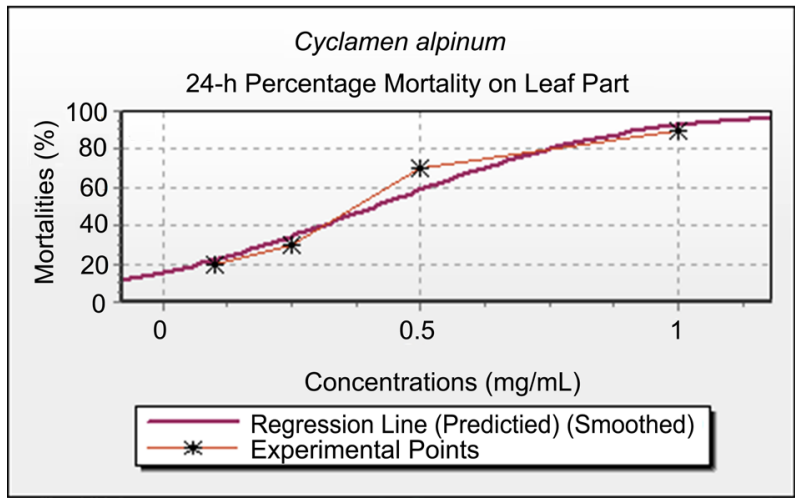

(a)

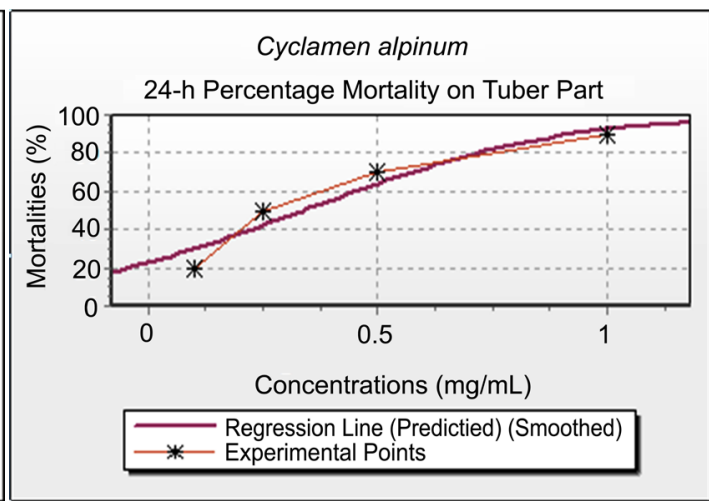

(b)

Figure 1. 24-hour percentage mortality graph of leaf part (a) and tuber part (b) of C. alpinum in Brine Shrimp Assay.

Table 5. Average mortality rates (\%) of the $C$. alpinum concentrations at the time of exposure to $A$. salina \pm S.E. and statistical values.

\begin{tabular}{ccc}
\hline & Leaf Part & Tuber Part \\
& 24 h Later & 24 h Later \\
\hline Control $\left(\mathrm{dH}_{2} \mathrm{O}\right)$ & 0 & 0 \\
& $\mathrm{~A}^{y}$ & $\mathrm{~A}^{y}$ \\
$0.1 \mathrm{mg} / \mathrm{mL}$ & $20 \pm 3.33$ & $20 \pm 3.33$ \\
& $\mathrm{~B}$ & $\mathrm{~B}$ \\
$0.25 \mathrm{mg} / \mathrm{mL}$ & $30 \pm 5.77$ & $50 \pm 5.77$ \\
& $\mathrm{~B}$ & $\mathrm{C}$ \\
$0.5 \mathrm{mg} / \mathrm{mL}$ & $70 \pm 11.55$ & $70 \pm 5.77$ \\
& $\mathrm{C}$ & $\mathrm{D}$ \\
$1 \mathrm{mg} / \mathrm{mL}$ & $90 \pm 3.33$ & $90 \pm 5.77$ \\
$\mathrm{LC}_{50}(\mathrm{~min})(\mathrm{mg} / \mathrm{mL})$ & $\mathrm{D}$ & $\mathrm{E}$ \\
$\mathrm{LC}$ & 0.167 & 0.121 \\
$\mathrm{LC}_{50}(\mathrm{mg} / \mathrm{mL})$ & 0.306 & 0.257 \\
$\mathrm{LC}$ & 0.518 & 0.434 \\
$(\mathrm{mg} / \mathrm{mL})$ & 1.171 & 1.073 \\
$\boldsymbol{x}^{2}$ & 0.61 & 0.01 \\
\hline
\end{tabular}

$y$. If lower cases are same in a column, there is no statistical difference in Duncan's multiple range test $(p \leq$ $0.05)$.

parts of the C. alpinum plant affect the 2nd and 3rd larval stages of $C x$. pipiens are shown in Table 6 . In this study, the lowest mortality at $1 \mathrm{mg} / \mathrm{mL}$ was observed on the leaf part after 72 hours exposure, but there is no significant difference in the tuber part. In tuber part, $100 \%$ death occurred at $0.25 \mathrm{mg} / \mathrm{mL}$ concentration after 72 hours of exposure. The $\mathrm{LC}_{50}$ values against the 2 nd and $3 \mathrm{rd}$ larval stages larvae of $C x$. pipiens were $0.534 \mathrm{mg} / \mathrm{mL}$ for leaf part extract and 0.151 $\mathrm{mg} / \mathrm{mL}$ for the tuber part extract (Figure 2). In leaf part, there is statistical difference between all concentrations after 72 hours exposure $(p<0.005)$. In tuber part, there is no statistical difference between concentrations of $0.25 \mathrm{mg} / \mathrm{mL}, 0.5$ $\mathrm{mg} / \mathrm{mL}$ and $1 \mathrm{mg} / \mathrm{mL}$ after 72 hours exposure ( $p>0.005)$. In Koc's study [41], it was mentioned that the effect of Melia azedarach extract on mosquito larvae may explain that this extract may cause serious damage to the gastrointestinal 


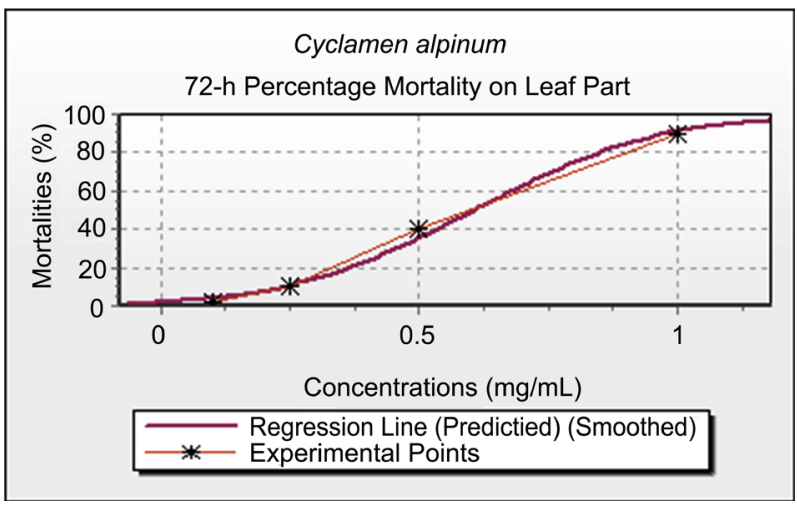

(a)

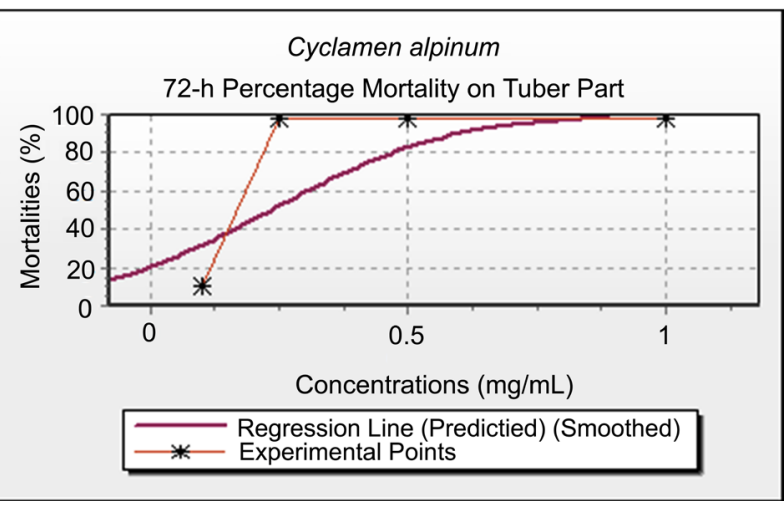

(b)

Figure 2. 72-hour percentage mortality graph of leaf part (a) and tuber part (b) $C$. alpinum in larvicidal effect against $C X$. pipiens.

Table 6. Average mortality rates (\%) of the $C$. alpinum concentrations at the time of exposure to $C X$. pipiens \pm S.E. and statistical values.

\begin{tabular}{ccccccc}
\hline & Leaf Part & Leaf Part & Leaf Part & Tuber Part & Tuber Part & Tuber Part \\
& 24 h later & $\mathbf{4 8}$ h later & 72 h later & 24 h later & 48 h later & 72 h later \\
\hline \multirow{2}{*}{ Control $\left(\mathrm{dH}_{2} \mathrm{O}\right)$} & 0 & 0 & 0 & 0 & 0 & 0 \\
& $\mathrm{a}^{x}, \mathrm{~A}^{y}$ & a, A & a, A & $\mathrm{a}^{x}, \mathrm{~A}^{y}$ & a, A & a, A \\
$0.1 \mathrm{mg} / \mathrm{mL}$ & 0 & 0 & 0 & 0 & 0 & $10 \pm 3.33$ \\
& a, A & a, A & a, A & a, A & a, A & a, B \\
$0.25 \mathrm{mg} / \mathrm{mL}$ & 0 & 0 & $10 \pm 0.33$ & 0 & $70 \pm 5.77$ & $100 \pm 0.00$ \\
& a, A & a, A & a, A & a, A & b, B & c, C \\
$0.5 \mathrm{mg} / \mathrm{mL}$ & 0 & $10 \pm 0.33$ & $40 \pm 0.57$ & 0 & $80 \pm 3.33$ & $100 \pm 3.33$ \\
& a, A & b, A & c, B & a, A & b, C & c, C \\
$1 \mathrm{mg} / \mathrm{mL}$ & $70 \pm 0.88$ & $80 \pm 1.20$ & $90 \pm 1.33$ & $10 \pm 3.33$ & $100 \pm 3.33$ & $100 \pm 0.00$ \\
$\mathrm{LC}_{50}(\mathrm{~min})(\mathrm{mg} / \mathrm{mL})$ & 0.636 & 0.577 & 0.382 & 0.176 & 0.164 & 0.108 \\
$\mathrm{LC}_{50}(\mathrm{mg} / \mathrm{mL})$ & 0.924 & 0.760 & 0.534 & 1.383 & 0.244 & 0.151 \\
$\mathrm{LC}_{50}(\mathrm{max})(\mathrm{mg} / \mathrm{mL})$ & 1.343 & 1.021 & 0.769 & 1.827 & 0.341 & 0.195 \\
$\mathrm{LC}_{90}(\mathrm{mg} / \mathrm{mL})$ & 1.119 & 1.152 & 1.059 & 1.915 & 0.502 & 0.277 \\
$\mathbf{x}^{2}$ & 8.28 & 28.30 & 6.93 & 3.35 & 0.94 & 0.59 \\
\hline
\end{tabular}

$x$. If lower cases are same in a line, there is no statistical difference in Duncan's multiple range test $(p \leq$ 0.05). $y$. If lower cases are same in a column, there is no statistical difference in Duncan's multiple range test $(p \leq 0.05)$.

tract cells. In this study, the same effect may be observed due to saponins in the content of $C$. alpinum plant [42].

\subsection{Analysis of Phenolic Compounds in HPLC}

Phenolic compounds and quantities determined by HPLC from C. alpinum plant are given in Table 7 and Figure 3. In the study, 9 phenolic compounds were identified; Gallic acid $(10.01 \mu \mathrm{g} / \mathrm{g}), 3,4$ dihydroxy benzoic acid $(33.65 \mu \mathrm{g} / \mathrm{g})$, 4 hydroxy benzoic acid $(125.33 \mu \mathrm{g} / \mathrm{g})$, Chlorogenic acid $(2.73 \mu \mathrm{g} / \mathrm{g})$, Vanillic acid $(121.35 \mu \mathrm{g} / \mathrm{g})$, Caffeic acid $(0.13 \mu \mathrm{g} / \mathrm{g}), \mathrm{p}$-coumaric acid $(5.78 \mu \mathrm{g} / \mathrm{g})$, Ferulic acid $(3.25 \mu \mathrm{g} / \mathrm{g})$, Cinnamic acid $(2.25 \mu \mathrm{g} / \mathrm{g})$. The amount of phenolic substances at the 
Table 7. Content quantities of standard phenolic compounds determined by HPLC.

\begin{tabular}{cccccccccc}
\hline & $\mathbf{1}$ & $\mathbf{2}$ & $\mathbf{3}$ & $\mathbf{4}$ & $\mathbf{5}$ & $\mathbf{6}$ & $\mathbf{7}$ & $\mathbf{8}$ & $\mathbf{9}$ \\
\hline Quantity $(\boldsymbol{\mu g} / \mathrm{g})$ & 10.01 & 33.65 & 125.33 & 2.73 & 121.35 & 0.13 & 5.78 & 3.25 & 2.25 \\
Retention Time (min) & 7.8 & 12.2 & 18.1 & 19.9 & 22.1 & 23 & 30.3 & 35.7 & 71.1 \\
\hline
\end{tabular}

1: Gallic acid, 2: 3.4 dihydroxy benzoic acid, 3: 4 hydroxy benzoic acid, 4: Chlorogenic acid, 5: Vanillic acid, 6: Caffeic acid, 7: p-coumaric acid, 8: Ferulic acid, 9: Cinnamic acid.

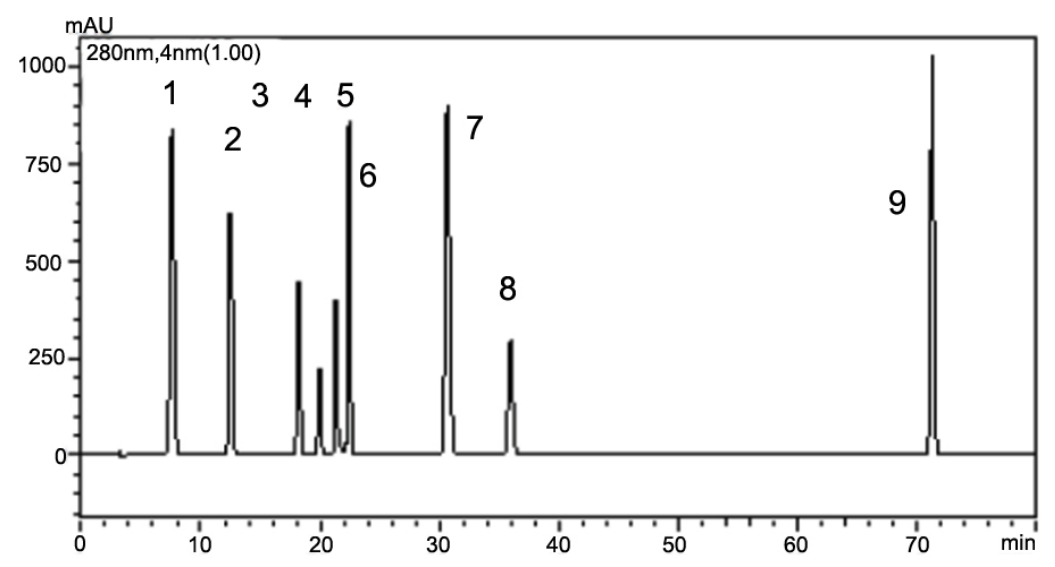

(a)

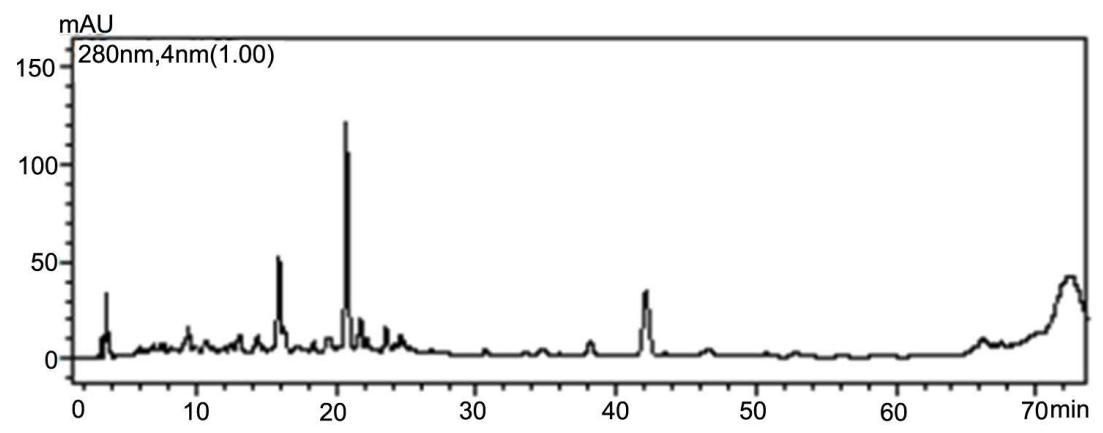

(b)

Figure 3. Standard (a) and sample (b) chromatograms of C. alpinum.

end of the HPLC may vary according to the method of extraction of the plant and the conditions of the region it is growing [43].

\subsection{Assay of Antimicrobial Activity}

The study of Ruiz-Ruiz [44] in the antimicrobial activity rating system is taken into consideration that inhibition region smaller than $10 \mathrm{~mm}$ is inactive, 10.0 $13.0 \mathrm{~mm}$ inhibition zone is partially active, $14.0-19.0 \mathrm{~mm}$ inhibition zone is active and inhibition region greater than $19.0 \mathrm{~mm}$ inhibition zone is very active. The antimicrobial activities of different $C$. alpinum extracts tested by disc diffusion method were shown in Table 8. There are some values of inhibitions zones except inactive which are determined in experiment with studying the antibiotics of ampicillin and penicillin and effects on microorganisms of extracts of $C$. alpinum with disc diffusion assay. The highest inhibitory zone of penicillin 
Table 8. Antimicrobial activities of the Ampicillin, Penicilin and extracts of $C$. alpinum (Inhibition zone diameter, $\mathrm{mm} \pm$ S.E.).

\begin{tabular}{|c|c|c|c|c|c|c|c|c|}
\hline \multirow{2}{*}{$\begin{array}{c}\text { Test } \\
\text { microorganisms }\end{array}$} & \multicolumn{8}{|c|}{ Antibiotics and plant extracts } \\
\hline & $A$ & $P$ & CTM & CTE & CTA & CLM & CLE & CLA \\
\hline $\begin{array}{c}\text { Escherichia coli } \\
\text { ATCC } 35218\end{array}$ & 21 & $\mathrm{nt}$ & $8 \pm 2$ & $11 \pm 2$ & - & $4 \pm 1$ & - & $8 \pm 1$ \\
\hline $\begin{array}{c}\text { Staphylococcus } \\
\text { aureus } \\
\text { ATCC } 25923\end{array}$ & $\mathrm{nt}$ & 34 & $6 \pm 1$ & $8 \pm 2$ & $6 \pm 1$ & - & $5 \pm 0$ & $8 \pm 0$ \\
\hline $\begin{array}{c}\text { Staphylococcus } \\
\text { aureus } \\
\text { ATCC } 12598\end{array}$ & $\mathrm{nt}$ & 6 & - & $7 \pm 2$ & - & $6 \pm 0$ & - & $5 \pm 1$ \\
\hline $\begin{array}{c}\text { Pseudomonas } \\
\text { aeruginosa NRLL } \\
\text { B-23 }\end{array}$ & 4 & nt & $8 \pm 2$ & - & $7 \pm 1$ & - & $6 \pm 0$ & $9 \pm 1$ \\
\hline $\begin{array}{c}\text { Bacillus subtilis } \\
\text { ATCC } 6633\end{array}$ & $\mathrm{nt}$ & 14 & - & $4 \pm 0$ & $8 \pm 1$ & - & $11 \pm 2$ & $5 \pm 1$ \\
\hline $\begin{array}{c}\text { Bacillus cereus } \\
\text { RSKK } 863\end{array}$ & $\mathrm{nt}$ & 27 & $6 \pm 1$ & $9 \pm 1$ & - & $10 \pm 2$ & $5 \pm 1$ & - \\
\hline $\begin{array}{l}\text { Candida albicans } \\
\text { ATCC } 10239\end{array}$ & 3 & nt & $9 \pm 2$ & $6 \pm 1$ & $12 \pm 2$ & - & $9 \pm 2$ & $6 \pm 1$ \\
\hline
\end{tabular}

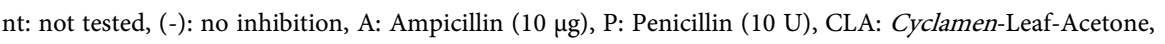
CLE: Cyclamen-Leaf-Ethanol, CLM: Cyclamen-Leaf-Methanol, CTA: Cyclamen-Tuber-Acetone, CTE: Cyclamen-Tuber-Ethanol, CTM: Cyclamen-Tuber-Methanol.

action was Staphylococcus aureus (ATCC 25923) with $34 \mathrm{~mm}$. The ethanol extract of the tuber part is partially active $(11 \pm 2 \mathrm{~mm})$ against the Escherichia coli (ATCC 35218), acetone extract of the tuber part is partially active $(12 \pm 2 \mathrm{~mm})$ against candida albicans (ATCC 10239), methanol extract of the leaf part is partially active (10 $\pm 2 \mathrm{~mm}$ ) against Bacillus cereus (RSKK 863$)$ and ethanol extract of the leaf part is partially active $(11 \pm 2 \mathrm{~mm})$ against Bacillus subtilis (ATCC 6633). The results of all other extracts from C. alpinum plant were inactivated.

\subsection{Assay of Anthelmintic Activity}

The percentage of mortality in which the ethanolic extracts of tuber and leaf parts of the C. alpinum plant against Tubifex tubifex are shown in Table 9. After 6 minutes, it was seen that tuber part $\left(\mathrm{LC}_{50}: 0.52 \mathrm{mg} / \mathrm{mL}\right)$ is more toxic than leaf part $\left(\mathrm{LC}_{50}: 1.32 \mathrm{mg} / \mathrm{mL}\right)$ with $\mathrm{LC}_{50}$ value.

\section{Conclusion}

The results showed that processed $C$. alpinum extracts exhibited in varying degrees of phenolic content, antimictobial and antioxidant properties and obtained weaken oxidative stress by its antioxidant properties. C. alpinum consumption may play a role in preventing human diseases that interfere with free radicals such as cancer, cardiovascular disease and aging. However, further investigation is needed on phenols, flavonoids, active substance, antioxidant activity and different antioxidant mechanisms, larvicidal effects of mosquito and antimicrobial properties. 
Table 9. Mortality rates (\%) of the $C$. alpinum concentrations at the time of exposure to Tubifex tubifex and statistical values.

\begin{tabular}{|c|c|c|c|c|c|c|}
\hline & $\begin{array}{c}\text { Leaf Part } \\
2 \text { min later }\end{array}$ & $\begin{array}{l}\text { Leaf Part } \\
4 \text { min later }\end{array}$ & $\begin{array}{l}\text { Leaf Part } \\
6 \text { min later }\end{array}$ & $\begin{array}{l}\text { Tuber Part } \\
2 \text { min later }\end{array}$ & $\begin{array}{l}\text { Tuber Part } \\
4 \text { min later }\end{array}$ & $\begin{array}{l}\text { Tuber Part } \\
6 \text { min later }\end{array}$ \\
\hline Control $\left(\mathrm{dH}_{2} \mathrm{O}\right)$ & 0 & 0 & 0 & 0 & 0 & 0 \\
\hline $1 \mathrm{mg} / \mathrm{mL}$ & 0 & 20 & 50 & 0 & 30 & 60 \\
\hline $2.5 \mathrm{mg} / \mathrm{mL}$ & 0 & 40 & 60 & 0 & 50 & 80 \\
\hline $5 \mathrm{mg} / \mathrm{mL}$ & 0 & 50 & 70 & 0 & 60 & 80 \\
\hline $10 \mathrm{mg} / \mathrm{mL}$ & 20 & 70 & 90 & 20 & 60 & 90 \\
\hline $20 \mathrm{mg} / \mathrm{mL}$ & 30 & 70 & 90 & 40 & 70 & 90 \\
\hline $40 \mathrm{mg} / \mathrm{mL}$ & 40 & 80 & 100 & 50 & 80 & 100 \\
\hline $\begin{array}{c}\mathrm{LC}_{50}(\mathrm{~min}) \\
(\mathrm{mg} / \mathrm{mL})\end{array}$ & 25.58 & 3.85 & 0.41 & 28.99 & 2.28 & 0.23 \\
\hline $\mathrm{LC}_{50}(\mathrm{mg} / \mathrm{mL})$ & 44.07 & 4.99 & 1.32 & 36.47 & 3.44 & 0.52 \\
\hline $\begin{array}{c}\mathrm{LC}_{50}(\mathrm{max}) \\
(\mathrm{mg} / \mathrm{mL})\end{array}$ & 215.73 & 6.32 & 2.33 & 49.52 & 4.75 & 0.86 \\
\hline $\mathrm{LC}_{90}(\mathrm{mg} / \mathrm{mL})$ & 214.46 & 87.91 & 13.92 & 212.37 & 126.26 & 1.035 \\
\hline$x^{2}$ & 12.07 & 0.75 & 0.75 & 4.3 & 1.6 & 0.9 \\
\hline
\end{tabular}

\section{Acknowledgements}

This project supported by Scientific Projects Administration Unit (BAP) of Pamukkale University, Turkey (BAP Project No: 2015FBE002).

\section{Author Contributions}

Murat Turan did the assays, collected test results, analysed the statistical data and wrote the article. Ramazan Mammadov, designed the study, interpreted the results of data and helped with references.

\section{References}

[1] Adedapo, A.A., Jimoh, F.O., Afolayan, A.J. and Masika, P.J. (2009) Antioxidant Properties the Methanol Extracts of the Leaves and Stems of Celtis africana. Records of Natural Products, 3, 23-31.

[2] Zengin, G. and Aktümsek, A. (2014) Investigation of Antioxidant Potentials of Solvent Extracts from Different Anatomical Parts of Asphodeline anatolica E. Tuzlaci: An Endemic Plant to Turkey. African Journal of Traditional, Complementary and Alternative Medicines, 11, 481-488. https://doi.org/10.4314/ajtcam.v11i2.37

[3] Burits, M. and Bucar, F. (2000) Antioxidant Activity of Nigella savita Essential Oil. Phytotherapy Research, 14, 323-328. https://doi.org/10.1002/1099-1573(200008)14:5<323::AID-PTR621>3.0.CO;2-Q

[4] Mammadov, R., Ili, P., Vaizogullar, H. and Makasc1, AA. (2011) Antioxidant Activity and Total Phenolic Content of Gagea fibrosa and Romulea ramiflora. Iranian Journal of Chemistry and Chemical Engineering, 30, 57-62.

[5] Arıduru, R. and Arabacı, G. (2013) Ciğertaze Otu (Salvia officinalis) Bitkisinin Antioksidan Aktivitesinin Belirlenmesi. SA ̈U Fen Bilimleri Enstitüsü Dergisi, 17, 241-246. 
[6] Zoral, B.F. and Turgay, Ö. (2014) Çeşitli Gıda Atıklarının Toplam Fenolik Madde İçeriğinin, Antioksidanve Antimikrobiyal Aktivitelerinin Araştırılması. KSÜ Doğa Bilimleri Dergis, 17, 24-33. https://doi.org/10.18016/ksujns.03907

[7] Huo, B.L., Lu, R., Li, P., Liao, Y., Chen, R., Deng, C., Lu, C., Wei, X. and Li, Y. (2011) Antioxidant Activity, Total Phenolic, and Total Flavonoid of Extracts from the Stems of Jasminum nervosum Lour. Grasas Y Aceites, 62, 149-154. https://doi.org/10.3989/gya.066810

[8] Aydın, Ç., Özay, C. and Mammadov, R. (2015) Determination of Antioxidant Activities of Two Allium Species From Turkey: A. sibthorpianum and A. stylosum. Journal of Applied Biological Sciences, 9, 31-36.

[9] Velioglu, Y.S., Mazza, G., Gao, L. and Oomah, B.D. (1998) Antioxidant Activity and Total Phenolics in Selected Fruits, Vegetables, and Grain Products. Journal of Agricultural and Food Chemistry, 46, 4113-4117. https://doi.org/10.1021/jf9801973

[10] Thaipong, K., Boonprakob, U., Crosby, K., Cisneros-Zevallos, L. and Byrne, D.H. (2006) Comparison of ABTS, DPPH, FRAP, and ORAC Assays for Estimating Antioxidant Activity from Guava Fruit Extracts. Journal of Composition and Analysis, 19, 669-675. https://doi.org/10.1016/j.jfca.2006.01.003

[11] Nishaa, S., Vishnupriya, M., Sasikumar, J.M., Hephzibah, P.C. and Gopalakrishnan, V.K. (2012) Antioxidant Activity of Ethanolic Extract of MarantaarundinaceaJ. Tuberous Rhizomes. Asian Journal of Pharmaceutical and Clinical Research, 5, 85-88.

[12] Davis, P.H. (1978) Flora of Turkey and East Aegean Islands. Vol. 6. Edinburgh. University of Edinburgh Press, Edinburgh, 128-135.

[13] Mathew, B. and Ozhatay, N. (2001) The Cyclamen of Turkey: A Guide to the Species of Cyclamen Growing in Turkey. Cyclamen Society, London, $32 \mathrm{p}$.

[14] GöçmenTaşkın, B., Vardareli, N., Doğaç, E., Mammadov, R. and Taşkın, V. (2012) Genetic Diversity of Natural Cyclamen alpinum Populations. Turkish Journal of Biology, 32, 413-422.

[15] Oz, E., Koc, S., DincDusen, O., Mammadov, R. and Cetin, H. (2013) Larvacidal Activity of Cyclamen (Primulaceae) Extracts against the Larvae of West NILE VIRÜS VECTOR Culexpipiens (Diptera: Culicidae). Asian Pasific Journal of Tropical Medicine, 6, 449-452. https://doi.org/10.1016/S1995-7645(13)60072-3

[16] Dani, F., Mhammed, H., Chahine, H., Helene, R. and George, A. (2016) Effect of Cyclamen libanoticum (Myrsinaceae) Extracts against Th Maggots of the Housefly, Musca domestica (Diptera: Muscidae) and of the Bluebottle Fly, Calliphora Vomitoria (Diptera: Calliphoridae). International Journal of Plant, Animal and Environmental Sciences, 6, 33-38.

[17] Arslan, S., Ozgun, O., Celik, G., Semiz, A., Dusen, O., Mammadov, R. and Sen, A. (2011) Effects of Cyclamen trochopteranthumon Hepatic Drug-Metabolizing Enzymes. Archives of Biological Sciences, 63, 545-555. https://doi.org/10.2298/ABS1103545A

[18] Gündoğan, M.T. (2003) Cyclamen mirabile Hildebr. ve Cyclamen trochopteranthum O. Schwarz Türleri Üzerinde Bazı Fitokimyasal Araştırmalar. Master Thesis, Department of Biology, Muğla University, Kötekli.

[19] Mammadov, R., Düşen, O., Uysal Demir, D. and Köse, E. (2009) Antioxidant and Microbial Activities of Extracts from Tubers and Leaves of Colchicum balansae Planchon. Journal of Medicinal Plants Research, 3, 767-770.

[20] Wu, C., Chen, F., Wang, X., Kim, H., He, G., Haley-Zitlin, V. and Huang, G. (2006) Antioxidant Constituents in Feverfew (Tanacetum parthenium) Extract and Their 
Chromatographic Quantification. Food Chemistry, 96, 220-227. https://doi.org/10.1016/j.foodchem.2005.02.024

[21] Amin, I., Zamaliah, M.M. and Chin, W.F. (2004) Total Antioxidant Activity and Phenolic Content in Selected Vegetables. Food Chemistry, 87, 581-586. https://doi.org/10.1016/j.foodchem.2004.01.010

[22] Re, R., Pellegrini, N., Proteggente, A., Pannala, A., Yang, M. and Rice Evans, C. (1999) Antioxidant Activity Applying an Improved ABTS Radical Cation Decolorization Assay. Free Radical Biology \& Medicine, 26, 1231-1237. https://doi.org/10.1016/S0891-5849(98)00315-3

[23] Slinkard, K. and Singleton, V.L. (1977) Total Phenol Analyses: Automation and Comparison with Manual Methods. American Journal of Enology and Viticulture, 28, 49-55.

[24] Arvouet-Grand, A., Vennat, B., Pourrat, A. and Legret, P. (1994) Standardization d'uneextrait de propolis et identification des principaux constituents. Journal de Pharmacie de Belgique, 49, 462-468.

[25] Krishnaraju, A.V., Rao, T.V.N., Sundararaju, D., Vanisree, M., Tsay, H.S. and Subbaraju, G.V. (2005) Assessment of Bioactivity of Indian Medicinal Plants Using Brine Shrimp (Artemia salina) Lethality Assay. International Journal of Applied Science and Engineering, 3, 125-134.

[26] Caponio, F., Alloggio, V. and Gomes, T. (1999) Phenolic Compounds of Virgin Olive Oil; Influence of Paste Preparation Techniques. Food Chemistry, 64, 203-209. https://doi.org/10.1016/S0308-8146(98)00146-0

[27] Çetin, H., Cinbilgel, İ., Yanıkoğlu, A. and Gökçeoğlu, M. (2006) Larvicidal Activity of Some Labiate (Lamiaceae) Plant Extracts from Turkey. Phytotherapy Research, 20, 1088-1090. https://doi.org/10.1002/ptr.2004

[28] Collins, C.H., Lyne, P.M. and Grange, J.M. (1995) Micro Biological Methods. 7th Edition, Butterworths, London.

[29] Ajaiyeoba, E.O., Onocha, P.A. and Olarenqaju, O.T. (2001) In Vitro Anthelmintic Properties of Buchholziacoriaceae and Gynandropsis gynandra Extracts. Pharmaceutical Biology, 39, 217-220. https://doi.org/10.1076/phbi.39.3.217.5936

[30] IBM Corp. Released (2015) IBM SPSS Statistics for Windows. Version 23.0. IBM Corp., Armonk.

[31] Du, G., Li, M., Ma, F. and Liang, D. (2009) Antioxidant Capacity and the Relationship with Polyphenol and Vitamin C in Actinidia Fruits. Food Chemistry, 113, 557-562. https://doi.org/10.1016/j.foodchem.2008.08.025

[32] Aydın, Ç., TaşdelenÖzcan, G., Turan, M. and Mammadov, R. (2016) Phenolic Contents and Antioxidant Properties of Echinops ritro L. and E. tournefortii Jaup. Et. Spach Extract. International Journal of Secondary Metabolite, 3, 74-81.

[33] Wang, L., Wang, Z. and Li, X. (2013) Preliminary Phytochemical and Biological Activities Study of Solvent Extracts from a Cold-Field Fruit-Malus baccata (Linn.) Borkh. Industrial Crops and Products, 47, 20-28. https://doi.org/10.1016/j.indcrop.2013.02.029

[34] Wang, M., Li, J., Rangarajan, M., Shao, Y., La Voie, E.J. and Huang, T. (1998) Antioxidative Phenolic Compounds from Sage (Salvia officinalis). Journal of Agricultural and Food Chemistry, 46, 4869-4873. https://doi.org/10.1021/jf980614b

[35] Makasci, A.A., Mammadov, R., Dusen, O. and Isik, H.I. (2010) Antimicrobial and Antioxidant Activities of Medicinal Plant Species Ornithogalum alpigenums tapf. from Turkey. Journal of Medicinal Plants Research, 4, 1637-1642. 
[36] Lu, Y., Khoo, T.J. and Wiart, C. (2014) Antioxidant Activity Determination of Citronellal and Crude Extracts of Citronellal and Crude Extracts of Cymbopogon citratus by 3 Different Methods. Pharmacology \& Pharmacy, 5, 395-400. https://doi.org/10.4236/pp.2014.54047

[37] Yılmaz, A., Yıldız, S., Tabbouche, S., Kılıç, A.O. and Can, Z. (2016) Total Phenolic Content, Antioxidant and Antimicrobial Properties of Pleurotos ostreatus Grown on Lime (Tilia tomentosa) Leaves. Hacettepe Journal of Biology and Chemistry, 44, 119-124.

[38] Mammadov, R., Ozay, C., Dusen, O., Aydin, C., Yaka, H. and Dusen, S. (2016) Evaluation of Antioxidant, Antimicrobial and Cytotoxic Activities of Muscari muscarimi Medik. Bulb and Flower Extracts from Turkey. Fresenius Environmental Buletin, 25, 1679-1684.

[39] Couladis, M., Badisa, R.B., Baziou, P., Chaudhuri, S.K., Pilarinou, E., Verykokidou, E. and Harvala, C. (2002) Antioxidant and Cytotoxic Activities of Hypericum sp. on Brine Shrimps and Human Cancer Cell Lines. Phytotherapy Research, 16, 719-722. https://doi.org/10.1002/ptr.1042

[40] Olaleye, M.T. (2007) Cytotoxicity and Antibacterical Activity of Methanolic Extract of Hibiscus sabdariffa. Journal of Medicinal Plants Research, 1, 9-13.

[41] Koc, S., Evren, O.H. and Cetin, H. (2016) Evaluation of Some Plant Fruit Extracts for the Control of West Nile Virus Vector Culex pipiens (Diptera: Culicidae). Journal of Arthropod-Borne Diseases, 10, 595-601.

[42] Aydın, Ç. and Mammadov, R. (2017) İnsektisit Aktivite Gösteren Bitkisel Sekonder Metabolitlerve Etki Mekanizmas1. Marmara Pharmaceutical Journal, 21, 30-37. https://doi.org/10.12991/marupj.259878

[43] Kelebek, H., Kesen, S., Sabbağ, Ç. and Selli, S. (2012) Gemlik Zeytin Çeşidinden Elde Edilen Natürel Zeytinyağında Fenol Bileşiklerininve Antioksidan Kapasitenin Belirlenmesi. Gıda, 37, 133-140.

[44] Ruiz-Ruiz, J.C., Ramon-Sierra, J., Arias-Argaez, C., Magana-Ortiz, D. and Ortiz-Vazguez, E. (2017) Antibacterial Activity of Proteins Extracted from the Pulp of Wild Edible Fruit of Bromelia pinguin L. International Journal of Food Properties, 20, 220-230. https://doi.org/10.1080/10942912.2016.1154572 